Rafidain Journal of Science

Vol. 29, No. 4, pp. 8-13, 2020

DOI: 10.33899/rjs.2020.167308

https://rsci.mosuljournals.com

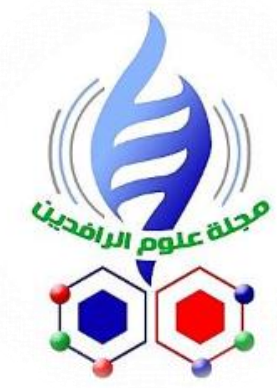

ISSN: 1608-9391

e-ISSN: 2664-2786

Received:2/7/2020

Accepted:24/9/2020

\section{Effect of Lipopolysaccharide Extracted from Enterobacter cloacae on some Pathogenic Bacteria}

*Rawaa A. Khalaf

**Hiyam A. ALtaii

Department of Biology / College of Science /University of Mosul

*E-mail: rawahhmed47@ gmail.com

**E-mail: hiyamaltaii @uomosul.edu.iq

\section{ABSTRACT}

A 106 different specimen were collected to isolate and diagnose some gram negative and gram-positive bacteria, as it was performed for the period from 15 August to 30 November 2019 from AL-Salam and Al-Khansaa educational hospitals in Mosul. Lipopolysaccharide (LPS) was extracted from Enterobacter cloacae by using the Methanol - Chloroform method. extract was diagnosed, using some biochemical tests such as the Molisch test to detect carbohydrate content and Folin reagent in order to determine proteins concentration, lipid solubility in organic solvent and Bio drop technique as well as to detect nucleic acid concentration. The extraction methods showed its efficiency with low protein and nucleic acids concentration in the extract. Lipopolysaccharide demonstrated its efficiency inhibiting microbial growth on all test isolates at concentrations $1100,1000 \mu \mathrm{g} \backslash \mathrm{ml}$ while its lipopolysaccharide showed its inhibition of Proteus mirabilis at all concentrations used. LPS showed possibility used as inhibitory, antimicrobial growth.

Keywords: Outer membrane, Inhibiting effect, Extraction, Lipopolysaccharide. 


\section{INTRODUCTION}

Outer membrane $(\mathrm{OM})$ of Gram negative (G-) bacteria are a round membrane enclosed entities of internal component cell (Jan, 2017). LPS anchored in the (OM) of all (G-) bacteria can pose risk to human health that ranges from irreversible shock to death ( $\mathrm{Su}$ and Ding, 2015). LPS have many benefits to bacterial cell as it contributes to the structural integrity and protection barrier against harsh environments (Reyes et al., 2015). Also, facilliting biofilm formation, antibiotic resistance and protecting bacteria from threats, LPS consist of three domains that include lipid A, core oligosaccharide and O-antigen (Huszczynski et al., 2020). LPS potent endotoxin causes chronic immune responses associated with inflammation (Salguero et al., 2019). Immune system responses to a low doses LPS lead to rapid clearing of pathogens but a higher doses LPS lead to uncontrolled over production cytokine that lead to endotoxic shock that is often lethal (Williams, 2019). In other word, less immunogenic LPS could serve as therapeutics to antagonize an overreacting innate immune system (Steimle et al., 2016). Enterobacter cloacae belonging to order Enterobacteriales, family Enterobacteriaceae gram negative bacteria bacilli shaped (DeLamaza et al., 2020). Facultative anaerobic it is related with opportunistic infections that is specific in immunocompromised patients (Hong et al, 2018).and nosocomial infections (Jin et al., 2018). Also, these bacteria have a broad-spectrum antibiotic resistance (Annavajhala et al., 2019). The extracted LPS by Methanol- Chloroform method was much easy less costly and safer but lack purity

(Kalambhe et al., 2017).

\section{MATERIALS AND METHODS}

A 106 specimen were collected that include urine, stool, blood, pus, sputum, nipple swab, vaginalis, nipple discharge and ear swab. The specimen was directly cultured on media then identification was completed depending on gram stain, morphological and biochemical tests using IMVIC to ensure diagnosis used a VITEK 2 technique was utilized. (Koneman et al., 2017; Cappuccino and Welsh, 2020; De-Lamaza et al., 2020).

\section{LPS extraction:}

LPS was extracted according to (Mirzae et al., 2011). The dried LPS was dissolved in deionized water and placed in the deep freezer $-80^{\circ} \mathrm{C}$ temperature then lyophilized placed in the lyophilizer (Christ lyophilizer made in Germany).

\section{Biochemical test to detect LPS:}

Folin to determine protein concentration, Molisch to detect carbohydrate, Solubility in organic solvent tests used to detect lipid also use Bio drop technique to detect nucleic acids concentration. (U and Sampath, 2014; Awasthi et al., 2013)

\section{Usage of crude of LPS as antibacterial against some pathogenic bacteria:}

The antibacterial activity of LPS was extracted from pathogenic Enterobacter cloacae done against Proteus mirabilis as gram negative bacteria and Staphylococcus aureus as gram positive bacteria, using agar well diffusion method according to (Chittepu, 2019). Experimental bacteria were cultured on petri Dish containing $25 \mathrm{ml}$ Muller Hinton agar after comparing bacterial growth with 0.5 McFarland standards tube that equals $1.5 \times 10^{8}$. A $(6 \mathrm{~mm})$ cut in agar diameter was performed by a sterile Pasteur pipette and then removed the agar cut by forceps filled $0.1 \mathrm{ml}$ of each well in the different concentration of LPS $(1100,1000,900,800,700) \mu \mathrm{g} \backslash \mathrm{ml}$ after being cultured with bacteria by swab (three replications were made for each concentration of LPS extract for each bacteria). Also, preparation control sample without of LPS using normal saline to fill in the well. The plats were incubated in $37^{\circ} \mathrm{C}$ for 24 hours in upright position to keep LPS extract in the well, then the effects LPS on microbial growth were evaluated by measuring the diameters of growth inhibition zones on pathogenic bacteria (Al-Azawy and Abdullah, 2017).

\section{Bacterial isolate:}

\section{RESULTS}

The following isolates were diagnosed: Enterobacter cloacae, Staphylococcus aureus and Proteus mirabilis. 
Biochemical Tests to Detect LPS:

Table 1: Biochemical tests for LPS

\begin{tabular}{|c|c|c|}
\hline The tests & The results & Concentration \\
\hline Folin & + & $0.0049 \mu \mathrm{g} \backslash \mathrm{ml}$ \\
\hline Molisch & + & Dark purple range \\
\hline Bio Drop & DNA $^{-}$, RNA + & DNA 0, RNA 598.2 ng/ $\mu 1$ \\
\hline Solubility In Organic Solvent & + & Lipid solubilized in methanol and chloroform \\
\hline
\end{tabular}

\section{Inhibitory Effect Crude Lipopolysaccharides:}

The antimicrobial activity assay of LPS extract of Enterobacter cloacae were done against experimental bacterial isolate in different concentrations of $(1100,1000,900,800,700) \mu \mathrm{g} \backslash \mathrm{ml}$ that were evaluated by measuring the diameters of growth inhibition zones on bacterial strain and the results are shown in (Tables 2,3 ).

Table 2: Inhibition zone diameter of lipopolysaccharide extract against Staphylococcus aureus by agar well diffusion method

\begin{tabular}{|c|c|c|c|c|}
\hline LPS concentrations $\boldsymbol{\mu g} \backslash \mathbf{m l}$ & \multicolumn{2}{|c|}{ size inhibition zone diameter (mm) } & 0 & 9.666667 \\
\hline 1100 & 16 & 13 & 0 & 7.666667 \\
\hline 1000 & 15 & 8 & 0 & 4 \\
\hline 900 & 12 & 0 & 0 & 0 \\
\hline 800 & 0 & 0 & 0 & 0 \\
\hline 700 & 0 & 0 & 0 & 0 \\
\hline Control Normal Saline & 0 & 0 & & 0 \\
\hline
\end{tabular}

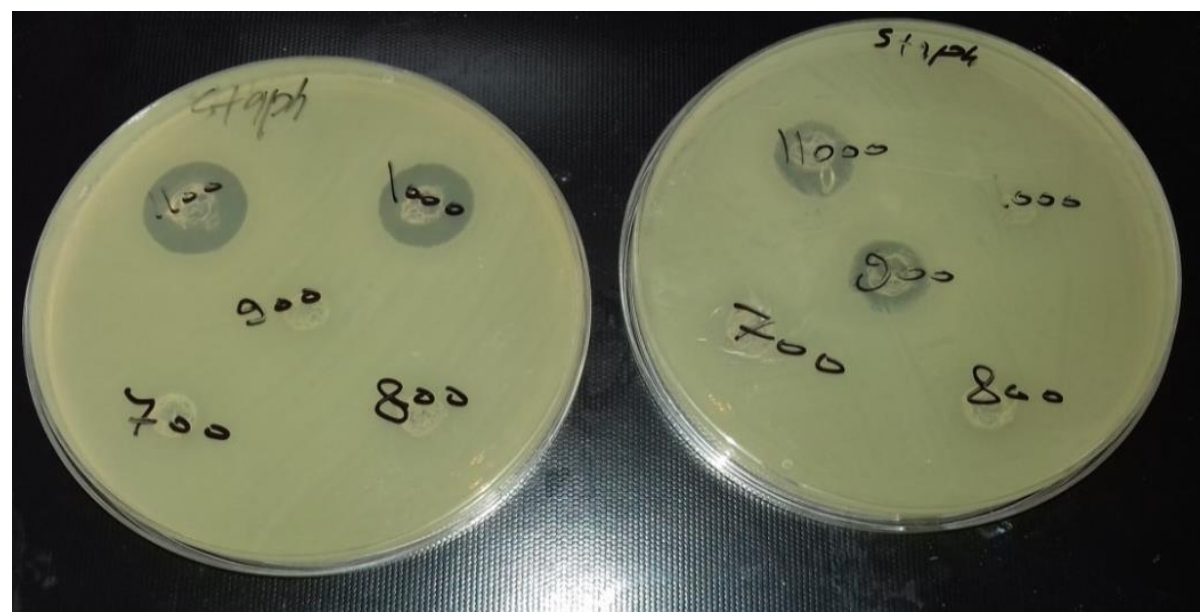

Fig. 1: Inhibition zone diameter for different concentration of LPS extract against Staphylococcus aureus by agar diffusion method.

Table 3: Inhibition zone diameter of lipopolysaccharide extract against Proteus mirabilis

\begin{tabular}{|c|c|c|c|c|}
\hline LPS concentrations $\boldsymbol{\mu g} \backslash \mathbf{m l}$ & \multicolumn{2}{|c|}{ size of inhibition zone diameter (mm) } & means \\
\hline 1100 & 20 & 22 & 19 & 19.66667 \\
\hline 1000 & 20 & 20 & 9 & 15.66667 \\
\hline 900 & 19 & 19 & 11 & 12.33333 \\
\hline 800 & 13 & 13 & 12 & 11.33333 \\
\hline 700 & 10 & 12 & 0 & 0 \\
\hline
\end{tabular}




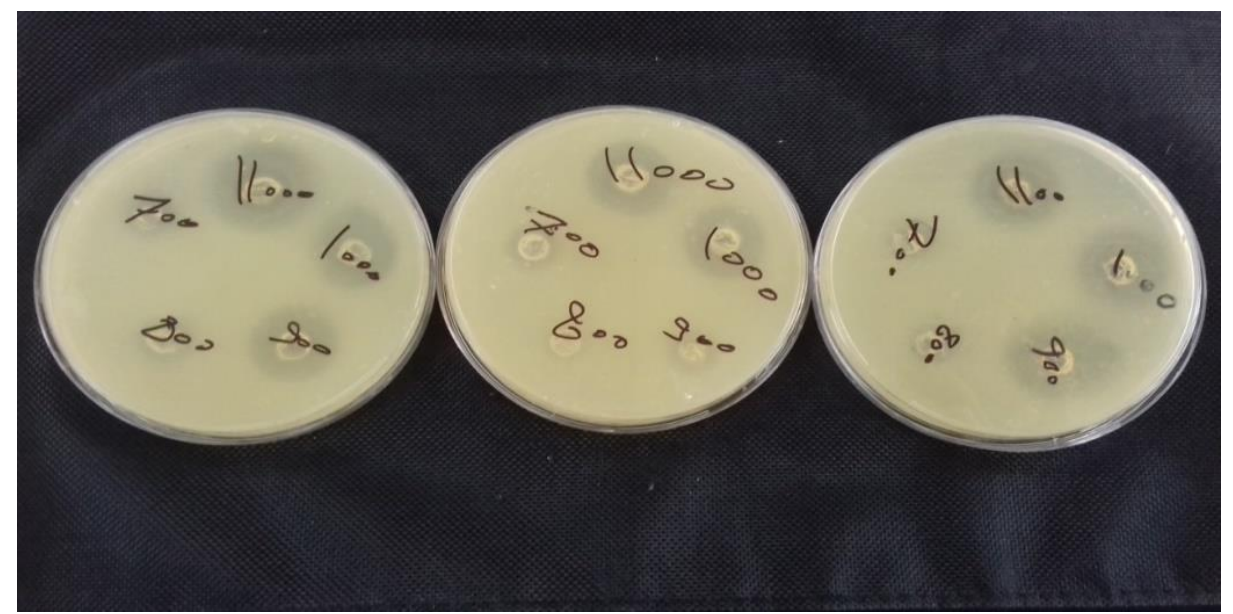

Fig. 2: Inhibition zone diameter for different concentration LPS extract against Proteus mirabilis by agar diffusion method

\section{DISCUSSION}

LPS has shown its efficacy as a growth inhibitor of pathological isolates at concentrations of $1000,1100 \mu \mathrm{g} \backslash \mathrm{ml}$, and with varying inhibition ratios at concentrations of at concentrations of 1100 , 1000, $900 \mu \mathrm{g} \backslash \mathrm{ml}$ affecting Staphylococcus aureus Fig. (1), and LPS has also demonstrated its efficacy in inhibiting Proteus mirabilis Fig. (2) at all concentrations $(1100,1000,900,800,700)$ $\mu \mathrm{g} \backslash \mathrm{ml}$. which lowest inhibitor concentration was only $700 \mu \mathrm{g} \backslash \mathrm{ml}$ for Proteus mirabilis among the isolates under study. And this inhibitory effect is compatible with the researcher (AL-Azawy and Abdullah, 2017). LPS effect on gram negative bacteria was more than gram positive bacteria. The LPS mechanisms inhibitory effect on microorganisms its effect on is due to its capability of having anti- adhesive agent that inhabits bacterial adhesion on the surface (Tanek et al., 2018) However, the mechanism of LPS antimicrobial remains indistinct but certain hypotheses were proposed that sustained specific evidence showing loss of membrane integrity: antimicrobial LPS is as a result of the adhesion property of the surface of active agents for the cell membrane integrity that leads to subsequent collapse of nutrition cycle or fatty acid moieties of LPS inserted in to the cell membrane. Instigates a proliferation of membrane size and ultra-structural changes, other hypothesis assumes that lps able to form pores and disrupt the plasma membrane (Ines and Dhouha, 2015). Also, LPS can increase cell membrane sponginess, occurs due to disarrangement of plasma membrane phospholipids (Sotirova et al., 2009), increasing permeability of plasma membrane cells as interact lipids with fatty acids content in the cell membrane leads to inhibition of the membrane -restricted enzyme and efflux of intracellular cytoplasmic components (Cameotra and Makkar, 2004). LPS interacting with membrane protein leads to increase initiating conformational changes of lipids and proteins (Ortiz et al., 2006; Sanchez et al., 2006; Sotirova et al., 2008).

\section{REFERENCES}

Al-Azawy, SH. J.; Abdullah, A.H. (2017). Study the inhibitory effect of purified lipopolysaccharide extracted from Proteus mirabilis on $E$ coli $\mathrm{O} 157: \mathrm{H} 7$ isolate from diarrheal infected animals. DJPS., 13(2), 282-295.

Annavajhala, M.K.; Simmonds, A.G.; Uhlemann, A. C. (2019). Multidrug resistant Enterobacter cloacae complex emerging as a Global diversifying threat. Frontiers in Microbiol., 10 (44), 1-8.

Awasthi, G.; Kumar, S.; Sanghi, A.; Singh, S.S. (2013). "Biochemistry Laboratory Manual”. India: International E- Publication.

Cameotra, S.S.; Makkar, R.S. (2004). Recent applications of biosurfactants as biological and immunological molecules. Current Opinion in Microbiol., 7, 262- 266. 
Cappuccino, J.G.; Welsh, C. (2020). "Microbiology a Laboratory Manual". $12^{\text {th }}$ ed. Hoboken, N.J.: Pearson education limited.

Chittepu, O.R. (2019). Isolation and characterization of biosurfactant producing bacteria from groundnut oil cake dumping site for the control of food borne pathogens. Grain and Oil Sci. and Technol., 2, 15-20.

De-Lamaza, L.M.; Pezzlo, M.T.; Bittencourt, C.E.; Peterson, E.M. (2020). "Color Atlas of Medical |Bacteriology." $3^{\text {rd }}$ ed. Washington, DC: ASM Press.

Hong, Y.K.; Lee, J.Y.; Sooko, K. (2018). Colistin resistance in Enterobacter spp isolate in Korea. J. Microbiol., 56(6), 433-440.

Huszczynki, S. M.; Lam, J.S.; KHursigara, C.M. (2020). The role of Pseudomonas aeruginosa lipopolysaccharide in bacterial pathogenesis and physiology. Pathogens J., 9(6), 2-22.

Ines, M.; Dhouha, G. (2015). Lipopeptide surfactants: Production, recovery and pore forming capacity. Peptides., 71,100-112.

Jan, A.T. (2017). Outer membrane vesicles (OMVS) of gram-negative bacteria a perspective up date. Frontiers in Microbiol., 8(1053), 2-11.

Jin, C.; Zhang, J.; Wang, Qi.; Chen, H.; Wang, X.; Zhang, Y.; Wang, H. (2018). Molecular characterization of carpapenm -resistant Enterobacter cloacae in 11 Chinese cities. Frontiers in Microbiol., 9(1597), 1-8.

Kalambhe, D.G.; Zade, N.N.; CHaudhar, S.P. (2017). Evaluation of two different lipopolysaccharide extraction methods for purity and functionality of LPS. Int. J. Curr. Microbial. APP. Sci., 6(3), 1296-1302.

Koneman, S., E.; Procop, G.W.; Church, D.; Hall, G.S.; Janda, W.M.; Schreckenberger, P.; Woods, G. (2017). "Color Atlas and Text Book of Diagnostic Microbiology ". $7^{\text {th }}$ ed. Philadelphia: Wolters Kluwer Health.

Mahalingam, P.; Sampath, N. (2014). Isolation characterization and identification of bacterial biosurfactant. Euro. J. Exp. Bio., 4(6), 59 - 64.

Mirzae, A.; Hedayati, M.; Ashttiani, H.R.; Rahbar, M.; Rastgar, H. (2011). A simple method for non-phenolic extraction of lipopolysaccharide from Salmonella typhimurium and Salmonella enteritidis with high purity and pyrogenicity in rat. Sci. Res. Essays., 6(5), 1101.

Ortiz, A.; Teruel, J. A.; Espuny, M. J.; Marques, A.; Marresa, A.; Aranda, F. J. (2006). Effects of dirhamnolipid on the structural properties of phsphatidyl choline membrane. International J. Pharmaceutics., 325(1), $99-107$.

Reyes, A.W.B.; Simborio, H.L.T.; Tanhop, H.; Arayan, L. T.; Ngochuy, T. X.; Min, W.; Kim, S. (2015). The two highly immunogenic antigens of Brucella lipopolysaccharide (LPS) and Outer Membrane Protein (OMPs). J. Prev. Vet. Med., 39(4), 198-206.

Salguero, M.V.; Al-OBaide, M.A.I.; Singh, R.; Siepmann, T.; Vasylyeva, T. L. (2019). Dysbiosis of gram-negative gut micro biota and the associated serum lipopolysaccharide exacerbates in flammation in type 2 diabetic patients with chronic kidney disease. Experim. and Therap. Medic., 18, 3461-3469.

Sanchez, M.; Teruel, J.A.; Espuny, M.J.; Marques, A.; Aranda, F.J.; Manresa, A.; Ortiz, A. (2006). Modulation of the physical properties of dielaidoylphsphatidyl ethanol amine membranes by a dirhamnolipid biosurfactant produced by pseudomonas aeruginosa. Chem. Phys. Lipids., 142(1), 118-127.

Sotirova, A.V.; Spasova, D.I.; Galabova, D.N.; Karpenko, E.; Shulga, A. (2008). Rhaminolipid biosurfactant permeabilizing effects on gram - positive and gram-negative bacterial strains. Current Microbiol., 56(6), 639- 644.

Sotirova, A.; Spasova, D.; Vasileva- Tonkova, E.; Galabova, D. (2009). Effects of Rhaminolipidbiosurfactant on cell surface of Pseudomonas aeruginosa. Microbiological Research., 164 (3), 297- 303. 
Steimle, A.; Autenrieth, I. B.; Frick, J.S. (2016). LPS sensing is necessary to fight pathogens. Internat. J. Medical Microbiol., 306, 290 -301.

Su, W.; Ding, X. (2015). Methods of endotoxin detection. J. Laborat. Autom., 20(4), 354-364.

Tanek, T.; Krasowska, A.; Czyznikowska, Z.; Lukazzewicz, M. (2018). Trehalose lipid biosurfactant reduce adhesion of microbial pathogens to polystyrene and silicone surface: an experimental and computational approach. Frontiers in Microbiol., 9 (2441), 1- 140.

Williams, K.L. (2019). "Endotoxin Detection and Control in Pharma Limulus and Mammalian Systems". Switzerland: Springer.

\section{تأثثر متعدد السكريات الاهني المستخلص من Enterobacter cloacae على بعض البكتيريا المرضية}

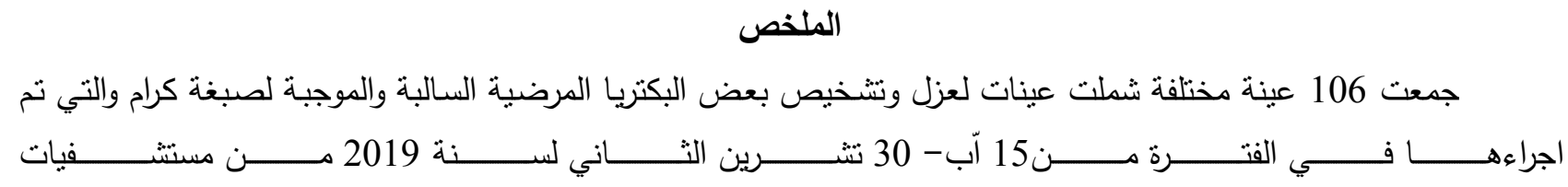

Enterobacter cloacae السلام والخنساء التعليمية في مدينة الموصل تم اجراء استخلاص متعدد السكريات الدهني لبكتيريا باستخدام طريقة الكلوروفورم - ميثانول ثم تشخيص مستخلص متعدد السكريات الدهني المستخلص باستخدام بعض الاختبارات الكيموحيوية مثل كاثنف فولن لتقدير تركيز البروتينات في المستخلص وكاثثف مولث للكثف عن السكريات واختبار الذوبانية في المذيبات العضوية للكثف عن الدهون واستخدام تقنية القطرة الحيوية للكثف عن تركيز الاحماض النووية في المستخلص الخام و اثبتت هذه الاختبارات كفاءة عملية الاستخلاص من خلال النسب الضئبلة للبروتينات والاحماض النووية في المستخلص واظهر

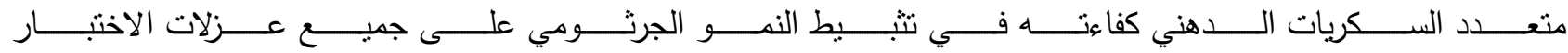

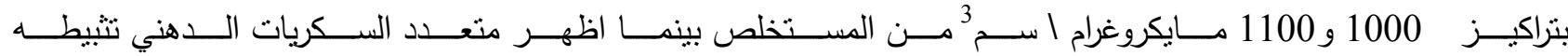
Proteus mirabilis الكلمات الدالة: الغشاء الخارجي، التأثير التثبيطي، الاستخلاص، متعدد السكريات الدهني. 